\title{
Activity Based Learning In A Freshman Global Business Course: Analyses Of Preferences And Demographic Differences
}

Mark F. Levine, (E-mail: mlevine@csuchico.edu), California State University, Chico Paul W. Guy, (E-mail: pguy@csuchico.edu), California State University, Chico

\begin{abstract}
The present study investigates pre-business students' reaction to Activity Based Learning in a lower division core required course entitled Introduction to Global Business in the business curriculum at California State University Chico. The study investigates students' preference for Activity Based Learning in comparison to a more traditional lecture and exam format. It also investigates whether or not students' with perceived interests in different aspects of business have preferences for activities that focus on different types of processes. It further analyzes whether or not gender and class standing play a significant role in these dynamics.
\end{abstract}

\section{LEARNING THEORIES}

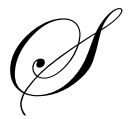

ince man emerged on earth learning has been an essential function for survival (Butcher 1997). For many years survival was the only thought that mattered to mankind. However, as the world became more civilized, some members of every society developed different ideas about the nature of learning (Butcher 1997). In this regard, learning has been defined as "the addition of knowledge or a skill by some type of change in behavior that occurs because of experience in a specified situation" (Barnhart 1989).

Theories of how people learn continue to be refined and redefined as the world we live in becomes more complex. Butcher describes general learning theory as a systematic approach that describes the process whereby people learn in relation to how they exist and interact with their environment (Butcher 1997). Although there are hundreds of individual theories of learning the two main categories of learning theory are behaviorist and cognitive.

Behaviorist learning theory, credited to the work of B.F. Skinner, states that knowledge exists independently and outside of people. This means that small bits of information get transferred to the learner. Learning takes place when a connection or series of connections are made between a stimulus and a response (Butcher 1997; Mergel 1998).

Cognitive learning theory, credited to the work of Jean Piaget, describes knowledge as a result of the "interaction of a particular structure and a person's own psychological environment" (Butcher 1997). In this case learning is "a modification of a person's world by an interaction process within which a person attains new insights or changes old ones" (Butcher 1997; Mergel 1998).

Activity Based Learning theory, the topic of this research, is a cognitive learning theory. This theory is considered a "constructivist" learning theory and is applied both to "learning theory and epistemology---both to how people learn, and to the nature of knowledge" (Hein 1991). Brooks and Brooks define constructivism:

It's a theory about knowledge and learning. Drawing on a synthesis of work in cognitive psychology, philosophy and anthropology, it defines knowledge as developmental, socially and culturally mediated, and thus, non-objective. 
Learning from this perspective is understood as a self-regulated process of resolving inner cognitive conflicts that often become apparent through concrete experience, collaborative discourse, and reflection" (Brooks \& Brooks 1993).

The latter part of this definition is truly a key to Activity Based Learning. Constructivism involves a learner constructing his own knowledge from current and/or past knowledge and experiences, actively seeking new information, and is actively engaged in the process of acquiring this knowledge (Butcher 1997). Each learner individually (and socially) constructs meaning - as he or she learns (Hein 1991). If this is true, Hein believes we are inevitably required to follow a pedagogy which provides learners with the opportunity to a) interact with sensory data, and b) construct their own world (Hein 1991).

\section{ACTIVITY BASED LEARNING}

Activity Based Learning (ABL) is a type of learning that occurs through a constructivist point of view. It is also referred to as problem based learning theory (Duch 1995). "At its most fundamental level, it is an instructional method characterized by the use of 'real world' problems as a context for students to learn critical thinking and problem solving skills, and acquire knowledge of the essential concepts of the course" (Duch 1995).

There are some principles of learning that suggest that ABL is very effective based on the way we gain, assimilate, and utilize knowledge and these principles should be kept in mind as we consider the role of ABL in education (Hein 1991).

1. Learning is an ACTIVE process in which the learner uses sensory input and then constructs meaning out of it. In other words the learner needs to "do something" that involves him/her engaging with the world.

2. People learn to learn as they learn. Learning is both constructing meaning and constructing systems of meaning. Each meaning we construct makes us better equipped to identify other similar patterns.

3. Constructing meaning happens in the mind, it is a mental process. We need to provide activities that engage the mind as well as the hands.

4. The language we use influences learning. Empirical evidence shows that people "talk to themselves" as they learn and further evidence attempts to prove that language and learning are deeply intertwined.

5. Learning is a social activity. Instead of isolating the learner as is common with traditional education methods it is important to understand that our learning is intimately associated with our connection with other human beings (teachers, peers, family, and casual acquaintances).

6. Learning occurs contextually. This makes it clear that learning is active and social. We cannot divorce learning from our lives.

7. One needs knowledge to learn, therefore any effort to teach must be connected to the state of the learner and provide a path into the subject for the learner based on his/her previous knowledge or experience.

8. It takes time to learn: learning is not instantaneous. For significant learning we need to revisit ideas, ponder them, try them out, play with them, and use them (Hein 1991).

Activity Based Learning provides an avenue to integrate learning within the students' knowledge and activities to provide an educational experience rich with sensory experience. Constructivism is not a fad of recent vintage however, it lacks substantial implementation in university classrooms.

\section{HISTORICAL BACKGROUND OF ACTIVITY BASED LEARNING}

Activity Based Learning is far from a "new" idea. The theory goes back at least as far as Socrates, and was a major emphasis among progressive educators like John Dewey (Dodge 1998). Although this theory has been around for quite some time, Dodge argues that in university education, we seem to have forgotten that learning is naturally an active process and involves putting students into situations that compel them to read, speak, listen, think deeply, and write (Dodge 1998). "While well delivered lectures are valuable and are not uncommon, sometimes the thinking required while attending class is low level comprehension that goes from the ear to the writing hand and leaves the mind untouched" (Dodge 1998). The key to ABL is that it puts the responsibility of organizing what is to be learned 
into the hands of the learners themselves, and in this way it ideally lends itself to a more diverse range of learning styles (Dodge 1998).

\section{ACTIVITY BASED LEARNING IN EDUCATION CURRICULUM}

Activity Based Learning has been used in curriculums for years however, mostly in private school settings. Recently, Montessori philosophy and methods, which are based on ABL theory, have spread rapidly in the public school system (Cohen \& Boyd 1996). In the past, Montessori institutions were nearly all private and private schools still remain the primary setting for this type of education. As of 1990, the Montessori approach was being used in about 110 public schools in 60 districts and is presently still growing.

"The 'secrets' of Montessori education are based on the work of Maria Montessori, an Italian physician and biologist born in 1870 who first worked with children labeled retarded and then with the children of poor families in inner-city Rome" (Cohen 1990). Her observations concluded that children learn best in an environment that respects and supports their individual development (Cohen 1990).

Maria proposed the idea of a "prepared environment" of multi-sensory materials, which relies heavily on practical skills and hands-on learning (Cohen 1990). In this setting children were encouraged to both enjoy and succeed at learning. The materials used in these settings are designed to help students gain an understanding of a whole process, rather than pieces of the concept and gives teachers a means to assess and evaluate progress by observation without formal testing (Cohen 1990).

\section{THE PRESENT STUDY}

\section{Impetus}

The impetus for the present study was the College of Business 10 year American Assembly of Collegiate Schools of Business (AACSB) re-accreditation review. Analysis of the then present undergraduate core curriculum revealed that much contextual material such as social, legal, ethical and global was being taken in an upper division core course after students had completed on average 93 units. To address this problem, a freshman course entitled BADM 101 - Introduction to Global Business was introduced into the lower division core curriculum in place of the previous upper division core course. In this manner, all business students must successfully complete the course before matriculating into the upper division.

\section{BADM 101 Pedagogy}

The Introduction to Global Business course at California State University, Chico, commonly referred to as BADM 101, is unique in the College of Business curriculum. The pedagogy of the course is based largely on Activity Based Learning, with the emphasis on individual assignments and group projects rather than exams. According to the California State University Chico 2005-2007 catalog the course description of BADM 101 is: "Using a combination of lecture, discussion, and activity-based participation, this course provides freshmen with an introduction to business with attention to the global context of the 21 st Century. This course guides students at an introductory level from idea generation and entrepreneurial behavior through financing, marketing, producing, and distributing products and services. The activities incorporate basic communication and computer literacy skills as well as library research and information competencies". http://www.csuchico.edu/catalog/cat05/.

Mentors are included in each section to provide added value to the ABL experience. The mentors hold three office hours a week to assist students needing any type of help on assigned activities. They also teach technology workshops to enhance the students' abilities to utilize technology in their assignments and familiarize the students with computer programs typically used in the College of Business degree program. 


\section{The Objective Of The Study}

The objective of the study is twofold. First, the study investigates the extent to which CSU Chico BADM 101 students prefer Activity Based Learning to the more traditional lecture and exam format. Second, the study investigates whether certain types of students, depending on their business interests, prefer different types of business related activities. Each of these questions of interest is further analyzed to see whether or not gender or class standing play an important role in these dynamics.

\section{The Hypotheses}

The aforementioned objectives resulted in the following four hypotheses in this study:

$\mathbf{H}_{1} \quad$ Pre-business students who intend to declare as business majors will prefer Activity Based Learning to the more traditional lecture and exam format.

$\mathbf{H}_{2}$ : $\quad$ Pre-business students who intend to declare as business majors will have a different level of preference for ABL than those who do not.

$\mathbf{H}_{3}$ : $\quad$ Pre-business students who intend to graduate in different business options (e.g., management, finance, marketing, etc.) will prefer activities which focus on different processes (e.g., creativity, discovery and quantitative analysis).

$\mathbf{H}_{4}$ : $\quad$ Neither gender nor class standing will have a significant effect on any of the conclusions of the other three hypotheses.

\section{The Sample}

The sample for the study consisted of 380 students enrolled in, and who took the final exam in, 9 sections of BADM 101. These sections were taught by 5 different instructors during the fall 2005 semester.

\section{The Instrument}

A simple 9-point anchored scale was used to collect data on students' preference for Activity Based Learning versus the more traditional lecture and exam format. "High Preference for ABL" anchored one end of the scale and "High Preference for Traditional Lecture and Exam" anchored the other. Similar 9-point scales were used for students' level of interest in the three activity processes (creativity, discovery, and quantitative analysis).

In order to investigate whether students who intend to graduate in different business majors (e.g., management, finance, marketing, etc.) prefer activities that focus on different processes, it was first necessary to classify the eight activities.

A co-author and two mentors who worked directly with BADM 101 students in presenting, teaching, and grading assignments initially heuristically clustered the eight activities. These activities which are currently completed in BADM 101 and formed the basis for the clustering are as follows: ${ }^{12}$

- Activity 1 - "New Flavor" - The objective of this individual activity is for students to invent a new flavor of ice cream for Ben \& Jerry and write a one-page press release to introduce the flavor. The activity invites students to use their imagination, be creative and include ideas for promotions and advertising themes. An additional purpose of this activity is to make sure students understand how to download graphics off a web site (Ben \& Jerry) and embed them into a word document.

- $\quad$ Activity 2 - "Excel Personal Budget" - For this individual activity, students must create a budget for their planned monthly income and expenses through the end of the semester. Two columns of information should

\footnotetext{
${ }^{1}$ The course web site lists Activity 2 as a book report/critique. It was not considered to be an ABL activity and thus eliminated from this investigation. The activities have thus been renumbered here simply to put them into a continuous sequesnce.

${ }^{2}$ For group activities the class is divided into 10 groups with 4-5 members each.
} 
be maintained for each month: Planned Revenue and Expenses and Actual Revenue and Expenses. During the semester, students are to enter their actual revenue and expenses in the appropriate spreadsheet cells. This information is handed in on a monthly basis. An additional purpose of this activity is to help students understand a corporate income statement.

- Activity 3 - "Stock Market Investment Club" - This group activity (4-5 students) is fairly in-depth and requires an in-class and out of class assignment. The objective is to introduce students to the stock market, familiarize them with common terms, and give them some hands-on experience dealing with investing and portfolio management.

- Activity 4 - "Corporate Valuation \& Information" - In this group activity the students are asked to research and report on 10 assigned companies. The report should describe the 10 companies chosen on key features reviewed in class. The report should include, though not be limited to, the following information: 1) CEOs name, 2) Board of Directors and the companies for which they work, 3) SIC code for the company, 4) stock market ticker symbol, 5) founding date, 6) sample of companies it owns, 7) parent company (if there is one), 8) stock price, and 9) main products of the company and its competitors. Students are also asked, at a later date, to give a formal presentation on one of the companies to the class utilizing Power Point software (see activity 7).

- Activity 5 - "Inter-team Memo" - In this group activity, each team member is required to attend at least one College of Business student organization meeting. After attending the meeting, he/she must write a short (1-2 pages) memorandum to their other team members describing the organization, its purpose and their experience at the meeting. Each team should review common business memorandum formats and establish a standard for their members to follow.

- Activity 6A - "Import Shop: Focus Group" - In this activity student groups have been hired to do research for Chico Import Shop (CIS). CIS has requested that the group identify global products that the target market (college students) would be interested in. Each team designs a questionnaire/survey that will be used to provide accurate information regarding the top 5 products to import from abroad (see Activity 6B). Teams, acting as focus groups, will identify 10 items as the basis for their questionnaire.

- Activity 6B - "Import Shop: Market Research" - Each group will design a questionnaire (type of questionnaire to be assigned) based on the ten items they identified as a focus group. Each group member will then collect completed surveys from 10 students (target market) on campus. The surveys will next be brought to class where we will analyze them and discover the top 5 import items for each group.

- Activity 6C - "Import Shop: Product Procurement" - Each Team will have approximately 1 week to surf the internet in order to "purchase" their top 5 products. Groups will report the type of product and country of origin, the URL of the web site where it was found, and the product per unit cost in US dollars.

- Activity 7 - "Company Presentations" - In this group activity each team will be assigned a company from activity 4 as the basis for a 10-15 minute PowerPoint presentation. While the content of each presentation is dependent upon the company chosen and the creativity of the presenting group, the activity does require some specific questions be answered about all companies.

- Activity 8 - "Human Resource Management" - The purpose of this individual activity is to determine opportunities for electronic recruiting and ways that companies benefit from the use of technology. Students approach the activity as members of a company considering switching recruitment of college graduates from visiting campuses and conducting personal interviews to using the World Wide Web. Students are asked to consider the benefits of using the World Wide Web for recruiting and make recommendations to their employer regarding the switch from on campus recruiting to online recruiting.

All of these activities can be found on the course website http://www.csuchico.edu/acms/BADM_101.

This heuristic clustering exercise resulted in 3 clusters representing activities that focused on different processes in their completion. These clusters were labeled creativity, discovery, and quantitative analysis by the authors. The distribution of activities within these clusters is as follows:

- $\quad$ Activity 1 - "New Flavor of Ice Cream" - Creative

- $\quad$ Activity 2 - "Excel Personal Budget" - Quantitative

- $\quad$ Activity 3 - "Stock Market" - Quantitative 
- $\quad$ Activity 4 - "Valuation \& Information" - Discovery

- $\quad$ Activity 5 - "Inter-team Memo" - Discovery

- $\quad$ Activity 6A - "Import Shop: Focus Group" - Creative

- $\quad$ Activity 6B - "Import Shop: Market Research" - Quantitative

- $\quad$ Activity 6C - "Import Shop: Product Procurement" - Discovery

- $\quad$ Activity 7 - "Company Presentations" - Creative

- $\quad$ Activity 8 - "Human Resource Management" - Discovery

\section{The Results}

Even though there were 380 students who took the survey at the time of the final exam, only 327 students reported that they intended to continue to pursue a degree in business (and $53 \mathrm{did}$ not). Three left some of the items blank. Thus some of the results below will show reduced sample sizes.

The first hypothesis is

$\mathbf{H}_{1}$ : Pre-business students who intend to declare as business majors will prefer Activity Based Learning to the more traditional lecture and exam format.

This was measured using a simple 9-point anchored scale with "high preference for ABL" as the low anchor coded 1, and "high preference for traditional lecture and exam" the high anchor coded 9. Since the mean of the 9-point scale is 5 , this first hypothesis is that the mean score on the above scale will be less than 5 , can be written as $\mathrm{H}_{1}: \mu<5$, and is tested with a t-test. The mean score of those who had declared an intention to major in business was 4.02, which is statistically smaller than $5(\mathrm{n}=326, \mathrm{t}=-36.3$, $\mathrm{p}$-value $=.000)$.

Table 1

\begin{tabular}{|c|c|c|c|}
\hline ABL Pref & $\#$ & $\mathbf{\%}$ & Declared Business Majors \\
\hline 1 & 48 & 15 & \\
2 & 48 & 15 & $\mathbf{H}_{1}: \boldsymbol{\mu}<\mathbf{5}$ \\
3 & 61 & 19 & $\mathrm{n}=326$ \\
4 Mean $=4.02$ \\
5 & 35 & 11 & $\mathrm{t}=-36.3$ \\
6 & 53 & 16 & $\mathrm{p}$-value $=.000$ \\
7 & 27 & 8 & \\
9 & 29 & 9 & \\
\hline
\end{tabular}

Another way to view the data is that $60 \%$ of the students answered 4 or less, whereas only $24 \%$ answered 6 or larger and $16 \%$ answered exactly 5 . See Table 1 .

In addition it was hypothesized $\left(\mathrm{H}_{4}\right)$ that neither gender nor class standing would have a significant effect on the pre-business students' preference for ABL. The mean ABL preferences of both the males and females, as expected, are statistically less than 5 . For the males, $\mathrm{n}=190$, mean $=4.04, \mathrm{t}=-5.93$, and $\mathrm{p}$-value $=.000$. And for the females, $\mathrm{n}=135$, mean $=3.98, \mathrm{t}=-5.26$, and $\mathrm{p}$-value $=.000$.

It is also interesting to know if the male and female students view ABL differently. For example, maybe one gender has a stronger preference ABL than the other. Or, maybe the distributions of ABL preferences (on the 9-point scale) are different for the male and female students. 
First, the data do not show a significant difference $(\mathrm{t}=.92, \mathrm{p}$-value $=.357)$ between the mean ABL preference of the males $(n=190$, mean $=4.04)$ and that of the females $(n=135$, mean $=3.98)$. Further, a test of the distributions of ABL preferences (shown in Table 2) shows no statistically significant difference between males and females $\left(\chi^{2}=5.08\right.$, $\mathrm{p}$-value $\left.=.749\right)$.

Table 2

\begin{tabular}{|c|c|c|c|c|c|}
\hline ABL Pref & Male & \multirow{2}{*}{$\begin{array}{c}\text { Female } \\
21\end{array}$} & & \multicolumn{2}{|c|}{ Declared Business Majors } \\
\hline 1 & 27 & & & $\mathrm{H}_{1}: \mu<5$ & $\mathrm{H}_{1}: \mu<5$ \\
\hline 2 & 26 & 23 & & Male & Female \\
\hline 3 & 41 & 19 & $\mathrm{n}$ & 190 & 135 \\
\hline 4 & 17 & 18 & Mean & 4.04 & 3.98 \\
\hline 5 & 32 & 21 & $\mathrm{t}$ & -5.93 & -5.26 \\
\hline 6 & 16 & 10 & p-value & .000 & .000 \\
\hline 7 & 16 & 13 & & \multirow{3}{*}{\multicolumn{2}{|c|}{$\begin{array}{l}\mathrm{H}_{\mathbf{1}}: \boldsymbol{\mu}_{\text {Male }} \neq \mu_{\text {Female }} \\
\mathrm{t}=.92 \\
\mathrm{p} \text {-value }=.357\end{array}$}} \\
\hline 8 & 6 & 5 & & & \\
\hline 9 & 9 & 5 & & & \\
\hline
\end{tabular}

To test if class standing will change the conclusion of $\mathrm{H}_{1}$, we first combine the juniors and seniors into one group, since there are so few seniors (7). The resulting means of the three class groups are all statistically less than 5 (see Table 3).

Table 3

\begin{tabular}{|c|c|c|c|}
\hline & \multicolumn{3}{|c|}{ Declared Business Majors } \\
\hline & $\mathrm{H}_{1}: \mu<5$ & $\mathrm{H}_{1}: \mu<5$ & $\mathrm{H}_{1}: \mu<5$ \\
\hline & Fresh & Soph & $\mathbf{J r} / \mathbf{S r}$ \\
\hline n & 176 & 55 & 95 \\
\hline Mean & 4.01 & 3.89 & 4.08 \\
\hline $\mathbf{t}$ & -5.79 & -4.10 & -3.85 \\
\hline p-value & .000 & .000 & .000 \\
\hline
\end{tabular}

Similar to comments above, it is interesting to know if the three classes view ABL differently. First, from an analysis of variance, the mean ABL preferences of the three class levels are not significantly different $(\mathrm{F}=.129$, $\mathrm{p}$ value $=.879$ ). Further, a test of the distributions of the ABL preferences (see Table 4) reveals no statistically significant differences among the three class levels $\left(\chi^{2}=12.67\right.$, $\mathrm{p}$-value $\left.=.697\right)$.

Table 4

\begin{tabular}{|c|c|c|c|c|c|c|c|}
\hline ABL Pref & Fresh & Soph & $\mathbf{J r} / \mathbf{S r}$ & & \multicolumn{3}{|c|}{ Declared Business Majors } \\
\hline 1 & 28 & 7 & 13 & \multirow{9}{*}{$\begin{array}{c}\mathrm{n} \\
\text { Mean }\end{array}$} & \multirow{2}{*}{\multicolumn{3}{|c|}{$\begin{array}{c}\mathrm{H}_{1} \text { : Mean ABL preferences } \\
\text { are different by class standing }\end{array}$}} \\
\hline 2 & 27 & 7 & 15 & & & & \\
\hline 3 & 31 & 12 & 18 & & Fresh & Soph & $\mathbf{J r} / \mathbf{S r}$ \\
\hline 4 & 13 & 10 & 12 & & 176 & 55 & 95 \\
\hline 5 & 35 & 8 & 10 & & 4.01 & 3.89 & 4.08 \\
\hline 6 & 13 & 3 & 10 & & \multicolumn{2}{|c|}{$\mathrm{F}=.129$} & $\mathrm{p}$-value $=.879$ \\
\hline 7 & 15 & 6 & 8 & & \multirow{3}{*}{\multicolumn{3}{|c|}{$\begin{array}{c}\mathrm{H}_{1} \text { : Distributions of } \mathrm{ABL} \text { preference } \\
\text { are different by class standing } \\
\chi^{2}=12.67 \quad \mathrm{p} \text {-value }=.697\end{array}$}} \\
\hline 8 & 6 & 1 & 4 & & & & \\
\hline 9 & 8 & 1 & 5 & & & & \\
\hline
\end{tabular}

Overall we conclude that pre-business students as a whole had a preference for Activity Based Learning. This conclusion is not affected by gender or class standing. Both genders and all three classes had mean preferences for $\mathrm{ABL}$ which were statistically less than 5 . 
The second hypothesis is:

$\mathbf{H}_{2}$ : $\quad$ Pre-business students who intend to declare as business majors will have a different level of preference for ABL than those who do not.

In the data there were 326 students who intended to major in business and 53 who did not. The mean ABL preferences for these two groups (business $=4.02$, non-business $=4.58)$ are marginally significantly different $(\mathrm{t}=1.70$; $\mathrm{p}$-value $=.090$ ). That is, the means are statistically different using a level of significance of $\alpha=.10$, but not using the more traditional $\alpha=.05$.

A test of the distributions of the ABL preferences of the business and non-business students also showed a marginally significant difference between the two groups $\left(\chi^{2}=14.10\right.$, p-value $\left.=.079\right)$. See Table 5 for these distributions.

Table 5

\begin{tabular}{|c|c|c|c|c|c|}
\hline ABL Pref & Bus & Non-Bus & \multicolumn{3}{|c|}{ All Students } \\
\hline 1 & 48 & 3 & \multicolumn{3}{|c|}{$\mathbf{H}_{2}: \mu_{\text {Bus }} \neq \mu_{\text {Non-Bus }}$} \\
\hline 2 & 48 & 7 & \multirow{3}{*}{$\begin{array}{c}n \\
\text { Mean }\end{array}$} & Bus & Non-Bus \\
\hline 3 & 61 & 10 & & 326 & 53 \\
\hline 4 & 35 & 4 & & 4.02 & 4.58 \\
\hline 5 & 53 & 16 & $\mathrm{t}$ & \multicolumn{2}{|c|}{1.70} \\
\hline 6 & 27 & 2 & $\mathrm{p}$-value & \multicolumn{2}{|c|}{.090} \\
\hline 7 & 29 & 3 & \multirow{3}{*}{\multicolumn{3}{|c|}{$\begin{array}{c}\mathrm{H}_{2} \text { : Distributions of ABL preferences are } \\
\text { different for Business and Non-Business } \\
\qquad \chi^{2}=14.10 \quad \mathrm{p} \text {-value }=.079\end{array}$}} \\
\hline 8 & 11 & 5 & & & \\
\hline 9 & 14 & 3 & & & \\
\hline
\end{tabular}

Hypothesis 4 says that neither gender nor class standing would affect the conclusion of $\mathrm{H}_{2}$. When we examine the males only, there is a statistically significant difference in mean ABL preference between the 189 students who intend to declare a business major and the 30 who do not (business mean $=4.05$, non-business mean $=$ $5.30, \mathrm{t}=2.88, \mathrm{p}$-value $=.004)$. For the females (135 business, 23 non-business), however, there is no significant difference between the means (business mean $=3.98$, non-business mean $=3.65, \mathrm{t}=.64$, $\mathrm{p}$-value $=.521$ ).

As is evident from Table 6 below, there is not enough data to test the distributions of the ABL preferences of the business and non-business students when we also consider gender.

Table 6

\begin{tabular}{|c|c|c|c|c|c|c|c|c|c|}
\hline ABL & Bus & Non-Bus & Bus & Non-Bus & & \multicolumn{4}{|c|}{ All Students } \\
\hline 1 & 27 & 1 & 21 & 2 & & \multirow{2}{*}{\multicolumn{2}{|c|}{$\frac{\mathrm{H}_{2}: \mu_{\text {Bus }} \neq \mu_{\text {Non-Bus }}}{\text { Male }}$}} & \multirow{2}{*}{\multicolumn{2}{|c|}{$\begin{array}{c}\mathrm{H}_{2}: \mu_{\text {Bus }} \neq \mu_{\text {Non-Bus }} \\
\text { Female }\end{array}$}} \\
\hline 2 & 25 & 2 & 23 & 5 & & & & & \\
\hline 3 & 41 & 2 & 19 & 8 & & Bus & Non-Bus & Bus & Non-Bus \\
\hline 4 & 17 & 2 & 18 & 2 & $\mathrm{n}$ & 189 & 30 & 135 & 23 \\
\hline 5 & 32 & 13 & 21 & 3 & Mean & 4.05 & 5.30 & 3.98 & 3.65 \\
\hline 6 & 16 & 2 & 10 & 0 & $\mathrm{t}$ & \multirow{2}{*}{\multicolumn{2}{|c|}{$\begin{array}{l}2.88 \\
.004\end{array}$}} & \multirow{2}{*}{\multicolumn{2}{|c|}{$\begin{array}{l}.64 \\
.521\end{array}$}} \\
\hline 7 & 16 & 3 & 13 & 0 & $\mathrm{p}$-value & & & & \\
\hline 8 & 6 & 3 & 5 & 2 & & & & & \\
\hline 9 & 9 & 2 & 5 & 1 & & & & & \\
\hline
\end{tabular}

With regard to class standing, among the freshmen, the mean ABL preference ratings of the business students and non-business students were not significantly different. Similarly, there is no significant difference among the business and non-business sophomores. However, within the junior/senior group, there is a significant difference in 
the ABL preferences between the business and non-business majors (Bus mean $=4.08$; Non-Bus Mean $=5.64 ; \mathrm{t}=$ $2.09 ; \mathrm{p}$-value $=.039)$, with the business group showing a greater preference (See Table 7).

Table 7

\begin{tabular}{|c|c|c|c|c|c|c|}
\hline & Fr & & Sop & res & & \\
\hline & $\mathrm{H}_{2}: \mu_{\mathrm{B}}$ & Non-Bus & $\mathrm{H}_{2}: \mu_{\mathrm{B}}$ & Non-Bus & $\mathbf{H}_{2}: \mu_{\mathrm{r}}$ & Non-Bus \\
\hline & Business & Non-Bus & Business & Non-Bus & Business & Non-Bus \\
\hline $\begin{array}{c}\mathbf{n} \\
\text { Mean }\end{array}$ & $\begin{array}{r}176 \\
4.03 \\
\end{array}$ & $\begin{array}{c}29 \\
4.24 \\
\end{array}$ & $\begin{array}{c}55 \\
3.89 \\
\end{array}$ & $\begin{array}{c}13 \\
4.46\end{array}$ & $\begin{array}{c}95 \\
4.08\end{array}$ & $\begin{array}{c}11 \\
5.64\end{array}$ \\
\hline $\begin{array}{c}\mathbf{t} \\
\text { p-value }\end{array}$ & & & & & & \\
\hline
\end{tabular}

As is evident from Table 8 below, there is not enough data to test the distributions of the ABL preferences of the business and non-business students when we also consider class standing.

Table 8

\begin{tabular}{|c|c|c|c|c|c|c|}
\hline \multirow[b]{2}{*}{ ABL Pref } & \multicolumn{2}{|c|}{ Fresh } & \multicolumn{2}{|c|}{ Soph } & \multicolumn{2}{|c|}{$\mathbf{J r} / \mathbf{S r}$} \\
\hline & Bus & Non-Bus & Bus & Non-Bus & Bus & Non-Bus \\
\hline 1 & 28 & 3 & 7 & 0 & 13 & 0 \\
\hline 2 & 26 & 5 & 7 & 1 & 15 & 1 \\
\hline 3 & 31 & 2 & 12 & 6 & 18 & 2 \\
\hline 4 & 13 & 3 & 10 & 1 & 12 & 0 \\
\hline 5 & 35 & 11 & 8 & 1 & 10 & 4 \\
\hline 6 & 14 & 1 & 3 & 1 & 10 & 0 \\
\hline 7 & 15 & 1 & 6 & 2 & 8 & 0 \\
\hline 8 & 6 & 3 & 1 & 0 & 4 & 2 \\
\hline 9 & 8 & 0 & 1 & 1 & 5 & 2 \\
\hline Total & 176 & 29 & 55 & 13 & 95 & 11 \\
\hline
\end{tabular}

Overall, therefore, we have weak evidence to say that Hypothesis 2 is correct. The business students have a marginally ( $p$-value $=.090$ ) different level of interest in ABL than the non-business students. The data show that only males and students in junior/senior class standing exhibit a significant difference in ABL preference.

The third hypothesis is

H3: Pre-business students who intend to graduate in different business options will prefer activities which focus on different processes.

Table 9 shows the means for the scales of the three activity types (creative, quantitative, discovery) for each of the options in the College of Business: accounting, business information systems, finance, marketing, management, and human resource management. For each option, the three activity type means were tested to see if they are significantly different. The test used was analysis of variance with each student being a block. Also shown in the table are the results of these tests. 
Table 9

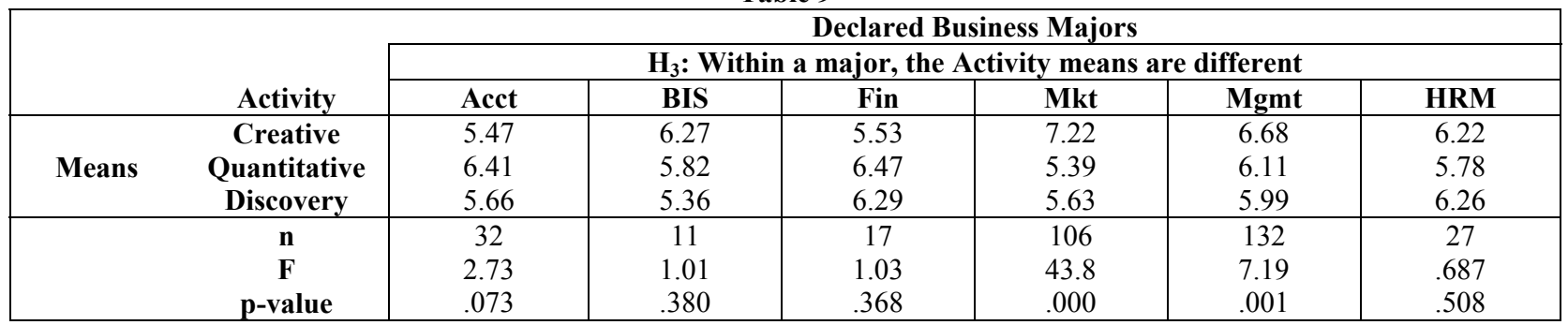

From this table we see there is evidence that hypothesis 3 is true. The marketing (p-value $=.000$ ) and management $(\mathrm{p}$-value $=.001)$ majors show a statistically significant preference for creative activities, the accounting majors show a marginally significant preference $(\mathrm{p}$-value $=.073)$ for quantitative activities, and no significant preference is shown for the other majors. (It is interesting to note, however, that even though not statistically significant for finance majors the quantitative mean was largest and the creative mean was smallest.)

Hypothesis 4 says that neither gender nor class standing will have a significant effect on the conclusion $\mathrm{H}_{3}$. Table 10 shows the same information as Table 9 (means and results of statistical tests-ANOVA), but now broken down by gender. An asterisk indicates that there is not enough data to carry out a statistical test for that gender/activity category.

Table 10

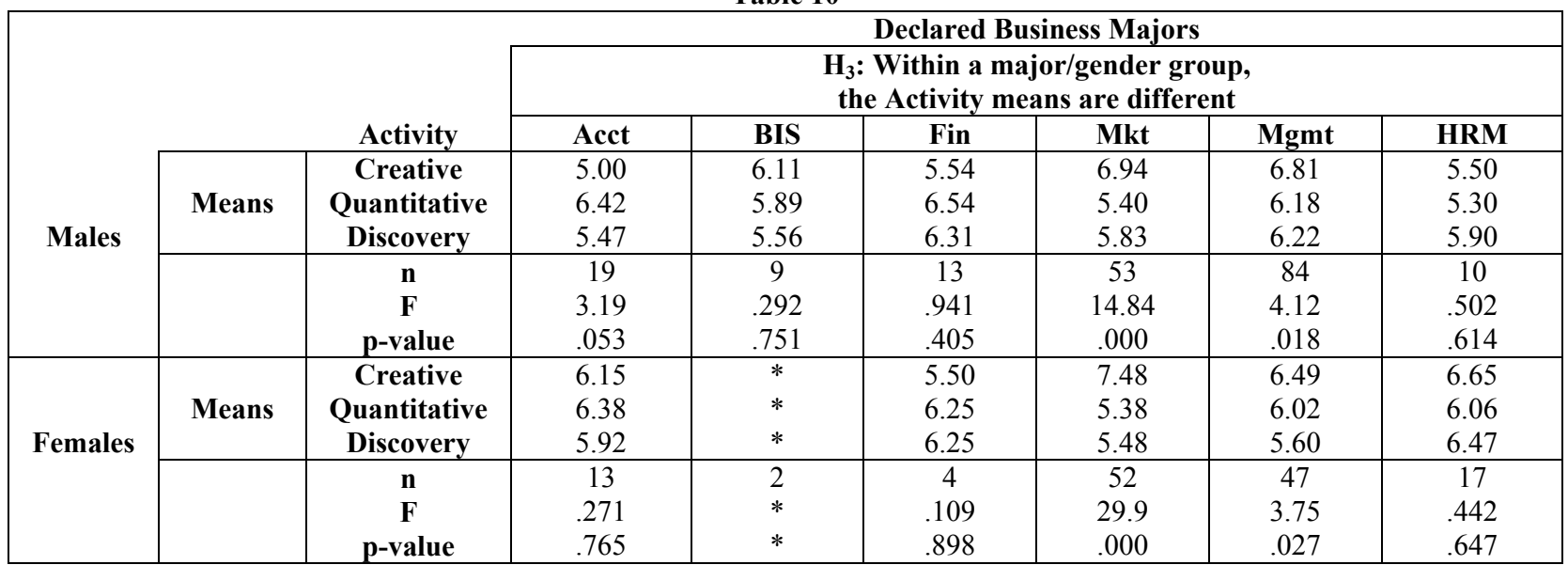

* Not enough data in this category to perform a test.

Hypothesis 3 above showed that marketing and management majors preferred creative activities and that no preference was shown (using a level of significance of .05) among the other majors. From Table 10 we see that marketing and management majors of both genders significantly prefer creative activities. Also no significant activity preferences are shown among BIS, finance, and HRM majors for both males and females. These results are consistent with the analysis above. In the accounting major, males prefer quantitative ( $p$-value $=.053$ ). Among the female accounting majors, the quantitative mean is the largest, but it is not statistically significantly larger.

Table 11 shows means and test results for the three class levels: freshmen, sophomores, and upper class (or $\mathrm{jr} / \mathrm{sr}$ ). Recall that there were not enough seniors (7) to treat them as a separate group. 
Table 11

\begin{tabular}{|c|c|c|c|c|c|c|c|c|}
\hline \multirow{9}{*}{ Freshmen } & & \multirow[b]{3}{*}{ Activity } & \multicolumn{6}{|c|}{ Declared Business Majors } \\
\hline & & & \multicolumn{6}{|c|}{$\begin{array}{c}\mathrm{H}_{3}: \text { Within a major/class standing group, } \\
\text { the Activity means are different }\end{array}$} \\
\hline & & & Acct & BIS & Fin & Mkt & Mgmt & HRM \\
\hline & \multirow{3}{*}{ Means } & Creative & 6.71 & 6.83 & 6.33 & 7.41 & 6.70 & 6.91 \\
\hline & & Quantitative & 6.64 & 5.67 & 6.83 & 5.26 & 5.93 & 5.82 \\
\hline & & Discovery & 5.93 & 5.50 & 5.50 & 5.50 & 5.93 & 5.82 \\
\hline & & n & 14 & 6 & 6 & 66 & 74 & 11 \\
\hline & & & 1.12 & 2.32 & .476 & 42.25 & 7.43 & 1.27 \\
\hline & & p-value & .342 & .149 & .635 & .000 & .001 & .302 \\
\hline \multirow{6}{*}{ Sophomores } & \multirow{3}{*}{ Means } & Creative & 5.14 & $*$ & $*$ & 7.15 & 6.76 & 6.60 \\
\hline & & Quantitative & 6.43 & $*$ & $*$ & 5.75 & 6.35 & 5.40 \\
\hline & & Discovery & 5.43 & $*$ & $*$ & 6.35 & 6.18 & 6.40 \\
\hline & & n & 7 & 2 & 3 & 20 & 11 & 5 \\
\hline & & & 1.89 & $*$ & $*$ & 4.06 & .541 & .805 \\
\hline & & p-value & .194 & $*$ & $*$ & .025 & .587 & .480 \\
\hline \multirow{6}{*}{$\mathbf{J r} / \mathbf{S r}$} & \multirow{3}{*}{ Means } & Creative & 4.09 & $*$ & 4.88 & 6.65 & 6.61 & 5.36 \\
\hline & & Quantitative & 6.09 & $*$ & 6.13 & 5.45 & 6.34 & 5.91 \\
\hline & & Discovery & 5.45 & $*$ & 6.63 & 5.35 & 6.02 & 6.64 \\
\hline & & n & 11 & 3 & 8 & 20 & 41 & 11 \\
\hline & & & 2.93 & $*$ & 1.72 & 3.54 & 1.05 & 2.26 \\
\hline & & p-value & .076 & $*$ & .215 & .039 & .356 & .130 \\
\hline
\end{tabular}

* Not enough data in this category to perform a test

Similar to what we saw before, using $\alpha=.05$, no statistically significant activity preferences are shown among accounting, BIS, finance, and HRM majors for all three class levels. For marketing majors, creative activities were statistically significantly preferred for all class standing groups. Among the management majors, only the freshmen show a statistically significant preference for creative activities. In the sophomore and $\mathrm{jr} / \mathrm{sr}$ groups, the creative means are the largest, but not significantly so.

Overall there is statistical evidence that hypothesis 3 is true. Students who intend to graduate in different business options do prefer activities which focus on different processes (e.g., creativity, discovery and quantitative analysis). This is true for the students as a whole, for male and female students, and for students of different class levels.

\section{CONCLUSION}

Pre-business students of both genders and all class standing prefer ABL to traditional lecture pedagogy. When we compare ABL preference of students who intend to declare business as a major with those who do not, the results are mixed. Only males and students with $\mathrm{jr} / \mathrm{sr}$ class standing significantly prefer ABL over those who do not intend to declare business as a major.

There is also some support for the hypothesis that students who intend to graduate in different business options will prefer activities which focus on different processes. This is most evident in the finding that marketing and management majors as a whole, and each gender analyzed separately, prefer "creative" activities. Furthermore, marketing majors of all class standing preferred "creative" activities. Among management majors, only freshmen showed a statistically significant preference for "creative" activities.

\section{FUTURE RESEARCH}

Based on this limited experience it seems reasonable to conclude that there is a legitimate role for ABL in university business curriculum. One possible explanation for the modesty of some of the results may be attributed to the fact that students entering as freshman are more accustomed to lecture, memory and test learning routines and are 
not used to the consistency of effort required in ABL settings. It is suggested that more research into the efficacy and outcomes of $\mathrm{ABL}$ research be carried out at both the lower division and upper division core courses within university business degree programs. It is further suggested that the efficacy of ABL be examined in other disciplines such as engineering.

\section{REFERENCES}

1. Barnhart, C.L. and Robert K. (Ed). (1989). World Book Dictionary. Chicago: World Book, Inc.

2. Brooks, J.G. and Brooks, M.G. (1993). In Search of Understanding: The Case for Constructivist Classrooms. Alexandria, VA: Association for Supervision and Curriculum Development.

3. Butcher, Deanna. (1997). An Overview of Learning Theory with an emphasis on Problem Based Learning [On Line] Available: http://www.usd.edu/ knorum/learningpapers/pbl.html.

4. $\quad$ Cohen, D.L. (1990). Montessori methods in public schools. Education Digest.

5. Cohen, E.B., and Boyd, E.C. (1996). Teaching techniques that work: College of teaching of information systems.

6. Dodge, Bernie. (1998). Active Learning on the Web [On Line] Available: http://edweb.sdsu.edu/people/bdodge/ActiveLearning.html.

7. Duch, B.J. (Ed). (1995). What is Problem-Based Learning? A Newsletter for the Center for Teaching Effectiveness [On Line] Available: http://www.udel.edu/pbl/cte/jan95-what.html.

8. Hein, George E. (1991). Constructivist Learning Theory [On Line] Available: http://www.exploratorium.edu/IFI/resources/constructivistlearning.html.

9. $\quad$ Mergel, Brenda. (1998). Instructional Design \& Learning Theory [On Line] Available: http://www.usask.ca/education/coursework/802papers/mergel/brenda.htm.

10. BADM 101: Understanding Global Business. College of Business, CSU Chico (2001). [On Line] Available: http://www.csuchico.edu/acms/BADM_101.

11. California State University Catalog (2005-2007). BADM 101 Course Description, CSU Chico (2005-2007). [On Line] Available: http://www.csuchico.edu/catalog/cat05/ 